\title{
Pengaruh Financial Capital, dan Literasi Keuangan terhadap Kinerja Usaha Kecil dan Menengah (UKM) di Kota Malang
}

\author{
Marija1, Sihwahjoeni², Gaguk Apriyanto ${ }^{3}$ \\ 1 Universitas Merdeka Malang, Jalan Terusan Raya Dieng no 62 - 64, kota Malang, 65164, Indonesia \\ 2 Universitas Merdeka Malang, Jalan Terusan Raya Dieng no 62 - 64, kota Malang, 65164, Indonesia \\ 3 Universitas Merdeka Malang, Jalan Terusan Raya Dieng no 62 - 64, kota Malang, 65164, Indonesia
}

ISSN-P: 2338-6010

ISSN-E: 2721-3692

\begin{abstract}
Small and Medium Enterprises (SME) are businesses that are very helpful in improving the economy of the community. SMEs need special attention to maintain their existence in the business world. However, various problems are still faced by SMEs in Malang, these problems are related to capital, bookkeeping, standardization, marketing and sales. The purpose of this study was to analyze the effect of financial capital and financial literacy on the performance of small and medium enterprises (SME) in Malang. The research design used causality research with a survey method. The population as the sample is the owner of SME registered in the Cooperative and SME Office of Malang City. Respondents in this study were 91 SME owners engaged in manufacturing. Primary data used comes from distributing questionnaires that are given directly. The data analysis technique used multiple linear regression. The results showed that financial capital and financial literacy had a positive and significant effect on the performance of small and medium enterprises (SME) in Malang.
\end{abstract}

Keywords: Financial capital; SME performance; financial literacy.

\section{ABSTRAK}

Usaha Kecil dan Menengah (UKM) merupakan usaha yang sangat membantu dalam meningkatkan perekonomian masyarakat. UKM perlu mendapat perhatian khusus untuk mempertahankan eksistensinya di dunia bisnis. Namun berbagai permasalahan masih dihadapi oleh UKM di Malang, permasalahan tersebut terkait permodalan, pembukuan, standardisasi, pemasaran dan penjualan. Tujuan penelitian ini adalah untuk menganalisis pengaruh financial capital dan financial literacy terhadap kinerja usaha kecil dan menengah (UKM) di Kota Malang. Desain penelitian menggunakan penelitian kausalitas dengan metode survei. Populasi sebagai sampel adalah pemilik UKM yang terdaftar di Dinas Koperasi dan UKM Kota Malang. Responden dalam penelitian ini adalah 91 pemilik UKM yang bergerak di bidang manufaktur. Data primer yang digunakan berasal dari penyebaran kuesioner yang diberikan secara langsung. Teknik analisis data menggunakan regresi linier berganda. Hasil penelitian menunjukkan bahwa financial capital dan financial literacy berpengaruh positif dan signifikan terhadap kinerja usaha kecil dan menengah (UKM) di Kota Malang.

Kata Kunci: Financial capital; kinerja UKM; literasi keuangan.

\section{PENDAHULUAN}

Usaha Kecil, dan Menengah (UKM) berperan strategis dalam pembangunan ekonomi nasional, karena selain berperan dalam pertumbuhan ekonomi dan penyerapan tenaga kerja juga berperan dalam pemerataan berbagai hasil pembangunan. Adanya sektor UKM, pengangguran akibat angkatan kerja yang tidak terserap di dunia kerja berkurang. Pertumbuhan usaha mikro telah menjadikan sumber pertumbuhan kesempatan kerja dan pendapatan. Dengan menyerap banyak tenaga kerja, berarti UMKM memiliki peran strategis dalam upaya pemerintah memerangi kemiskinan dan pengangguran.

Usaha Kecil dan Menengah (UKM) adalah usaha yang mepunyai peranan penting terhadap lajunya perekonomian nasional. UKM membantu dalam menyediakan lowongan pekerjaan baru untuk menciptakan tenaga kerja sehingga dapat mendukung pendapatan rumah tangga. Pengaruh besar yang diberikan oleh UKM terhadap pertumbuhan ekonomi, maka hal ini mengharuskan pemerintah memberikan perhatian khusus terhadap keberlangsungan usaha dan adanya pendukung dari penggunaan informasi yang akurat. Perhatian ini dilakukan agar terjalin link bisnis yang terarah antara pelaku usaha dengan elemen yang terkait, sehingga kinerja UKM terus lebih baik. kinerja UKM yang terus membaik 
dapat memberikan keuntungan tidak hanya untuk pemilik usaha itu sendiri, namun juga dapat memberikan keuntungan untuk negara.

Pertumbuhan usaha kecil dan menengah yang terus meningkat setiap tahunnya dan mampu bersaing dengan negara lain merupakan hal yang sangat bagus untuk pertumbuhan ekonomi. Namun, seiring dengan peningkatan jumlah UKM maka persaingan yang dihadapi pemiliki sangat tinggi terutama persaingan dalam ekspor. (Arbi 2019) menyampaikan bahwa kinerja ekspor nasional dari UKM masih terbilang rendah, yaitu hanya sebesar $15,80 \%$. Selain ekspor yang masih rendah, di Indonesia masih ada beberapa problem yang dihadapi oleh pemilik usaha. Problem tersebut adalah mengembangkan brand, desain yang mengikuti pasar, akses modal, dan akses pasar (www.cnbcindonesia.com). Berdasarkan pemasalahan yang dihadapi, mengharuskan adanya jalinan kerjasama antara pelaku usaha dan pemerintah terkait dalam mengatasi permasalahan yang terjadi agar kinerja UKM terus membaik.

Peran UKM yang sangat besar terhadap perekonomian nasional, maka terdapat strategi yang harus dilakukan dalam meningkatkan kinerja usaha. Strategi tersebut adalah dengan memberikan pembelajaran kepada pemilik usaha tentang pengetahuan akuntansi. Dalam akuntansi pemilik usaha dapat mengetahui tentang financial (keuangan), yaitu mengenai struktur modal awal yang digunakan, akses memperoleh modal, dan cara mengelola keuangan yang benar. Financial adalah salah satu faktor penting dalam mendirikan suatu usaha. Pemahaman tentang financial yang baik oleh pelaku usaha, maka mereka dapat dengan tepat dalam menentukan sumber financial yang akan digunakan dan cara mengelola keuangan yang baik. Dalam strategi ini financial capital dan literasi keuangan merupakan faktor yang dapat menilai seberapa baik pemahaman pelaku usaha mengenai keuangan pada perusahan yang dikelola.

Financial capital (modal keuangan) bisa dikatakan sebagai keahlian mengenai sumber keuangan yang digunakan oleh owner dalam mengawali dan mengelola usaha. Umumnya owner membangun bisnis dengan modal pribadi. Tetapi seiring berjalannya bisnis, pemilik usaha biasanya mengambil dana pinjaman untuk menambah modal pribadi dalam perluasan usaha. (O. O. Fatoki, 2011) dan (Rahmadani,2019) menunjukkan adanya pengaruh positif financial capital terhadap kinerja usaha. Pengaruh ini dapat dipengaruhi karena dengan ketersediaan modal yang cukup sebagai sumber permodalan usaha maka mempermudah dalam menjalankan usaha. Selain financial capital dalam mencapai kinerja yang baik dalam suatu kegiatan usaha, pemilik usaha perlu memahami bagaimana cara pengelolaan keuangan yang baik, yaitu dengan cara mengetahui tentang literasi keuangan (Kurniawan \& Setiawan , 2018).

Literasi keuangan adalah pengetahuan dan keyakinan seseorang tentang keuangan dalam proses memaksimalkan penetapan kebijakan dan pengelolaan keuangan. Kemampuan literasi keuangan pelaku usaha dapat menghasilkan kebijakan financial yang berkualitas untuk saat ini dan masa depan guna mencapai keberhasilan dan keberlangsungan usaha (Maghfiroh , 2019). Berdasarkan hasil survei (OJK, 2019) literasi keuangan masih didomisasi oleh masyarakat perkotaan yang mencapai $41,41 \%$, sedangkan literasi keuangan masyarakat pedesaan hanya mencapai 34,53\%. Berdasarkan survei tersebut menunjukkan tingkat literasi keuangan masyarakat perkotaan dan pedesaan masih tidak sama, padahal dapat kita ketahui bahwa literasi keuangan ini dapat memberikan pengaruh yang positif terhadap kinerja usaha. (Sanistasya et al., 2019), menemukan pengaruh positif literasi keuangan terhadap kinerja usaha. Literasi keuangan yang semakin baik maka pemilik usaha dalam mengelola keuangan akan semakin optimal dan menciptakan keputusan-keputusan yang tepat, sehingga akan berpengaruh terhadap kinerja usaha yang semakin baik (Putri \& Satria, 2019).

Kinerja UKM adalah efek yang dicapai melalui usaha yang dilakukan oleh pelaku usaha terhadap perusahaan. Kinerja yang berhasil berkaitan erat dengan seberapa mampu pemilik usaha dalam mengelola usahanya, hal ini dapat dilihat dari keuntungan yang diperoleh pemiliki berupa financial maupun non financial. Keberhasilan kinerja ini dipengaruhi oleh kemampuan pemilik dalam mengelola usaha berkaitan dengan penentuan Financial capital (modal keuangan), dan pengetahuan tentang pengelolaan keuangan (literasi keuangan). Financial capital berkaitan dengan perencanaan modal awal yang digunakan pemilik baik berasal dari modal pribadi atau pinjaman yang dikelola secara baik akan menentukan kinerja usaha (Rahmadani,2019). Selain penggunaan financial capital yang tepat, pengetahuan literasi keuangan juga dapat mempengaruhi kinerja usaha (Setiawan et al., (2018). Pengetahuan literasi keuangan yang tinggi, pemilik usaha memiliki pengetahuan bagaimana cara pengelolaan keuangan yang baik dalam kegiatan operasional sehingga kinerja yang dihasilkan akan terus membaik.

Penelitian ini dilakukan di kota Malang karena kota Malang merupakan salah satu daerah penyebaran UKM yang cukup banyak. Kota Malang juga merupakan kota tujuan wisata dan kota pendidikan, sehingga 
perkembanagan UKM terus mengalami peningkatan. Tingginya tingkat pertumbuhan usaha, kepala Dinas koperasi dan UKM kota Malang menyampaikan terdapat permasalahan yang dihadapi oleh pelaku usaha. Permasalahan yang kerap kali dihadapi oleh pelaku usaha adalah terkait dengan permodalan, pembukuan, standarisasi, pemasaran, dan penjualan. Hal ini menunjukkan bahwa pengetahuan pelaku usaha dalam meningkatkan kinerja usaha yang baik masih kurang, sehingga sulit bagi pelaku usaha untuk berkembang. Berdasarkan permasalahan tersebut, peneliti ingin melihat pengaruh dari financial capital dan literasi keuangan terhadap kinerja usaha kecil dan menengah (UKM) di Kota Malang

\section{Usaha Kecil dan Menengah (UKM)}

Usaha Kecil dan Menengah (UKM) merupakan usaha yang didirikan oleh perorangan yang memiliki kekayaan bersih tidak lebih dari 500 juta. UKM memiliki peran penting dalam pembangunan negara. Dengan demikian pemerintahan melalui dinas terkait melakukan beberapa strategi untuk tetap mempertahankan kinerja UKM disegala kondisi ekonomi. Adapun strategi tersebut adalah:

Mempermudah akses pasar dan memperbaiki pangsa pasar.

Memberikan kemudahan akses permodalan.

Memberikan edukasi tentang pengelolaan usaha menggunakan teknologi informasi.

Peningkatan manajemen dan organisasi.

Menjalin kemitraan secara baik.

\section{Kinerja UKM}

Kinerja UKM merupakan hasil kerja pelaku UKM yang di mulai dari berdirinya usaha sampai tercapainya tujuan yang telah direncanakan dengan melalui beberapa kerja dan penilaian yang telah ditentukan oleh perusahaan.

\section{Financial Capital}

Financial capital mengacu pada daya beli atau sarana yang mewakili kekayaan keuangan yang disimpan, biasanya dalam bentuk mata uang. Mata uang digunakan oleh perusahaan atau pengusaha perorangan untuk berinvestasi untuk memulai atau mengembangkan bisnis, yaitu untuk membeli atau memperoleh modal fisik. Menurut Curtiss (2012) financial capital terdiri dari hutang dan ekuitas.

\section{Literasi Keuangan}

Literasi keuangan merupakan pengetahuan, keterampilan, dan keyakinan yang dapat memengaruhi sikap dan perilaku seseorang sehingga dapat meningkatkan kualitas pengambilan keputusan dan pengelolaan keuangan demi mencapai tujuan yang telah direncanakan ( POJK, 2016). Literasi keuangan memiliki peran yang penting bagi UKM karena literasi keuangan dapat memberdayakan UKM tentang sumber-sumber pendanaan dan keterampilan yang akan membekali UKM untuk menimbang pilihan mereka dalam mencari pembiayaan untuk mengoptimalkan struktur keuangannya.

\section{Perumusan Hipotesis}

\section{Pengaruh Financial Capital terhadap Kinerja Usaha Kecil dan Menengah (UKM)}

Financial capital bisa disebut sebagai modal keuangan yang merupakan struktur modal yang dapatan menjamin kelangsungan usaha suatu perusahaan. Financial capital didalam suatu perusahaan berasal dari modal pribadi dan berasal dari pihak lain (investor dan bank). Modal yang telah ditanamkan diharapkan dapat diolah dengan sebaik-baiknya dengan tujuan memeperoleh keuntungan yang diharapkan dan juga untuk kelangsungan usaha. (Eniola \& Dada, 2018) menyatakan bahwa financial capital memilki nilai positif dan pengaruh yang besar terhadap kinerja UKM. (Md Saad, 2018) dalam penelitian menemukan bahwa financial capital selain dapat meningkatkan kinerja, financial capital juga dapat meningkatkan profitabilitas usaha.

$\mathrm{H}_{1}$ : Financial capital berpengaruh positif signifikan terhadap kinerja UKM

\section{Pengaruh Literasi Keuangan terhadap Kinerja Usaha Kecil dan Menengah (UKM)}

Literasi keuangan bertujuan dalam menilai baik buruknya seseorang dalam mengetahui dan 
mengaplikasikan tentang keuangan baik keuangan pribadi maupun keuangan perusahaan. Tingkat pemahaman pelaku bisnis mengenai litersi keuangan dapat berakibat pada penyelenggaraan dan akuntabilitas sehingga bisa dipertanggung jawabkan. Selain itu kemampuan literasi keuangan dapat berfungsi sebagai tahap awal dalam strategi bisnis. Penelitian (Arumsari, 2019) dan (Rakhmawati et al., 2018) menunjukkan terdapat pengaruh positif literasi keuangan terhadap kinerja UKM. Dengan semakin tinggi pengetahun UKM tentang literasi keuangan maka semakin meningkat pula kinerja dari usaha tersebut.

$\mathrm{H}_{2}$ : Literasi keuangan berpengaruh positif signifikan terhadap kinerja UKM

\section{METODE}

\section{Rancangan Penelitian}

Desain penelitian ini adalah penelitian kausalitas. (Anwar, 2016) penelitian kausalitas bertujuan untuk menjelaskan sebab-akibat antar variabel. Metode yang digunakan dalam mengumpulkan data dengan cara survei secara langsung kepada responden untuk mendapatkan informasi dan menarik kesimpulan.

\section{Populasi dan Sampel}

Populasi pada penelitian ini adalah UKM yang terdaftar di Dinas Koperasi dan UKM Kota Malang. Penentuan sampel menggunakan random sampling, sehingga diperoleh sampel sebanyak 91 UKM dari jumlah populasi sebanyak 536 usaha yang diperoleh dari Dinas Koperasi dan UKM Kota Malang.

\section{Teknik Pengunpulan Data}

Teknik pengumpulan data dengan menyebarkan kuesioner.

\section{Teknik Analisis Data}

Uji Regresi Linear Berganda

Persamaan regresi linear berganda pada penelitian ini dirumuskan sebagai berikut:

$Y=\alpha+\beta_{1} X_{1}+\beta_{2} X_{2}+e$

$$
\begin{array}{ll}
\mathrm{Y} & =\text { Variabel dependen, } \\
\mathrm{a} & =\text { Konstan, } \\
\beta_{1}, \beta_{2} & =\text { Koefisien regresi, } \\
\mathrm{X}_{1}, \mathrm{X}_{2} & =\text { Variabel independen. } \\
\mathrm{e} & =\text { Error }
\end{array}
$$

\section{Pengujian Hipotesis} t).

Pengujian hipotesis menggunakan uji simultan (uji f), uji koefisien determinan $\left(\mathrm{R}^{2}\right)$, dan uji perisal (uji

\section{HASIL DAN PEMBAHASAN}

\section{HASIL}

\section{Uji Regresi Linear Berganda}

Pengujian setiap variabel dilakukan menggunakan analisis regresi linear berganda yang bertujuan untuk mengetahui sejauh mana pengaruh variabel dependen terhadap variabel independen. Pengaruh ini dilihat dari kenaikan satu poin variabel independen maka variabel dependen akan naik sejumlah nilai Beta. Hasil uji tersebut, yaitu:

Tabel 1. Hasil Uji Regresi Linear Berganda

\begin{tabular}{clll}
\hline \multirow{2}{*}{ Model } & & \multicolumn{2}{c}{ Unstandardized Coefficients } \\
\cline { 3 - 4 } & & $\mathrm{B}$ & Std. Error \\
\hline & (Constant) & 24,381 & 4,529 \\
& Financial capital & 0,448 & 0,128 \\
& Literasi keuangan & 0,619 & 0,189 \\
\hline
\end{tabular}

Sumber: Data primer diolah, 2020.

Persamaan regresi berganda yang dilakukan: 
$Y=24,381+0,448_{1}+0,619_{2}+4,529$

\section{Uji F}

Uji F bertujuan untuk mengetahui apakah variabel independen secara simultan memiliki pengaruh terhadap variabel dependen pada tabel ANOVA. Hasil uji $\mathrm{f}$ dilihat melalu nilai signifikan $<0,05$ dan nilai $\mathrm{f}$ hitung $>$ dari $\mathrm{f}$ tabel, maka hasil tersebut menunjukkan bahwa variabel independen secara simultan memiliki pengaruh terhadap variabel dependen. Berikut hasil uji f:

\section{Tabel 2. Hasil Uji F}

\begin{tabular}{crl}
\hline Model & F & Sig. \\
\hline Regression & 3 & $0,000^{\mathrm{b}}$ \\
Residual & 0,339 & \\
Total & & \\
\hline Sumber: Data primer diolah, 2020.
\end{tabular}

Hasil uji F menunjukkan nilai f hitung 30,339 lebih besar dari $\mathrm{f}$ tabel $(3,10)$ dengan tingkat signifikansi 0,000. Hasil ini menunjukan bahwa variabel independen (financial capital dan lliterasi keuangan) secara simultan memiliki pengaruh terhadap variabel dependen (kinerja UKM).

\section{Uji Koefisien Determinan $\left(\mathbf{R}^{2}\right)$}

Uji koefisien determinasi $\left(R^{2}\right)$ bertujuan untuk menilai seberapa jauh kemampuan model dalam menerangkan varian variabel dependen.

Tabel 3. Hasil Uji Koefisien Determinan $\left(R^{2}\right)$

\begin{tabular}{cccll}
\hline Model & $\mathrm{R}$ & $\begin{array}{c}\mathrm{R} \\
\text { Square }\end{array}$ & Adjusted R Square & Std. Error of the Estimate \\
\hline 1 & $0,639^{\mathrm{a}}$ & 0,408 & 0,395 & 3,824 \\
\hline
\end{tabular}

Sumber: Data primer diolah, 2020.

Nilai koefisien determinan atau R Square sebesar 0,408 atau 40,8\%, artinya variabel yang diteliti (financial capital dan literasi keuangan) memberikan pengaruh terhadap kinerja UKM sebesar 40,8\% sementara sisanya 59,2\% dijelaskan variabel lain diluar variabel independen yang diteliti.

\section{Uji t}

Uji $\mathrm{t}$ dilakukan untuk melihat pengaruh setiap variabel independen terhadap variabel dependen dengan nilai signifikansi variabel $<0,05$.

Tabel 4. Hasil Uji t

\begin{tabular}{llll}
\hline Model & & T & Sig. \\
\hline 1 & (Constant) & 5,383 & 0,000 \\
& financial capital & 3,502 & 0,001 \\
& literasi keuangan & 3,273 & 0,002 \\
\hline
\end{tabular}

Sumber: Data primer diolah, 2020.

\section{PEMBAHASAN}

Financial capital berpengaruh positif dan signifikan terhadap kinerja usaha kecil dan menengah (UKM) di kota Malang, artinya semakin baik penerapan financial capital yang dilakukan maka tingkat kinerja usaha akan meningkat. Hasil penelitian ini sejalan dengan penelitian yang dilakukan oleh (Pramestiningrum \& Iramani, 2020) dan (Sombolayuk et al., 2019) yang telah menemukan pengaruh langsung financial capital terhadap kinerja usaha. Financial capital (modal keuangan) merupakan kemampuan dalam memperoleh sumber daya keuangan, membangun, dan mempertahankan modal rill yang memerlukan pemilik usaha memainkan peran aktif dalam kegiatan usaha. Penentuan modal yang digunakan dalam usaha baik modal 
sendiri maupun modal pinjaman sangat mempengaruhi pemilik dalam mengelola usaha dan hal tersebut dapat mepengaruhi kinerja usaha. Modal sendiri yang digunakan dalam membangun usaha dapat memberikan semangat dalam diri pemilik, karena pemilik usaha akan terus menciptakan ide-ide agar usahanya tetap berdiri di segala kondisi ekonomi dan memperoleh laba yangdiinginkan. Selain itu modal pinjaman juga dapat menambah semangat pemilik usaha dalam mengelola usaha, karena dengan modal pinjaman pemilik akan merasa ada kewajiban yang harus dipenuhi. Hal ini pemilik akan terus berusaha untuk memaksimalkan kinerja usaha. Seiring dengan meningkatnya kinerja maka akan meningkatkan keuntungan atau laba usaha. Pemilik usaha yang mampu dalam mengelola dan memanfaatkan keuntungan yang diperoleh akan menjadikan usaha tersebut semakin berkembang dan mampu bersaing dengan usaha lainnya.

Literasi keuangan berpengaruh positif dan signifikan terhadap kinerja usaha kecil dan menengah (UKM) di kota Malang, artinya pemahamanyang dimiliki oleh pelaku UKM mengenai pengelolaan keuangan sehingga menghasilkan keputusan yang tepat dalam operasional usaha dapat meningkatkan kinerja UKM yang semakin maksimal. Dengan pengelolaan keuangan yang benar pelaku usaha mampu merencanakan keuangan dalam jangjan pendek maupun jangka panjang, dan mengelola laporan keuangan, sehingga dengan ini UKM dapat meningkatkan efisiensi keuangan. Pelaku UKM yang yang memahami literasi keuangan akan selalu memaksimalkan kinerja usahanya dengan memiliki sifat kehatihatian dalam mengambil keputusan untuk meminimalisir kerugian. (Fatoki, 2014) berpendapat bahwa usaha dalam sektor UKM yang mempunyai pengetahuan literasi keuangan, akan mengelola usaha dan keuangan yang didirikan akan mencapai tujuan pengembangan yang semakin baik disetiap periodenya dan mampu bertahan ditengah krisis. Penelitian yang dilakukan Chepngetich (2016), Ningsih (2018), Maghfiroh (2019), dan Fardhansyah (2020), menemukan adanya pengaruh positif dan signifikan literasi terhadap kinerja UKM.

\section{SIMPULAN DAN SARAN}

\section{SIMPULAN}

Menurut hasil dan pembahasana yang telah dijelaskan maka simpulan yang diberikan sebagai berikut:

Financial capital berpengaruh positif dan signifikan terhadap kinerja usaha kecil dan menengah (UKM) di kota Malang, artinya keputusan dalam menentukan modal baik modal sendiri maupun modal pinjaman dalam mengelola usaha, serta kemampuan pemilik dalam mengelola keuntungan atau laba yang diperoleh akan meningkatkan kinerja UKM.

Literasi keuangan berpengaruh positif dan signifikan terhadap kinerja usaha kecil dan menengah (UKM) di kota Malang, artinya tingginya pengetahuan pemilik usaha tentang keuangan maka kinerja usaha akan lebih meningkatkan. Pemilik usaha akan lebih efektif dan efisien dalam pengelolaan keuangan.

\section{KETERBATASAN}

Banyaknya UKM yang tutup sementara karena masa pandemi COVID, sehingga komunikasi yang dilakukan kepada pemilik usaha menjadi terbatas.

Masih banyak pemilik usaha yang belum memahami tentang literasi keuangan sehingga membuat peneliti menjelaskan secara rinci tentang pengertian dan tujuan dari variabel tersebut.

Model varian variabel yang dihasilkan financial capital dan literasi keuangan terhadap kinerja UKM relatif rendah yaitu mendekati nol, sehingga dapat dikatakan model varian penelitian ini lemah.

\section{SARAN}

Penelitian yang akan datang diharapkan untuk meneliti faktor-faktor lain dari variabel yang sudah diteliti yang mungkin berpengaruh besar terhadap kinerja UKM, dan memperluas lokasi penelitian.

Sebaiknya Pemerintah memberikan edukasi mengenai pengelolaan keuangan karena masih terdapat beberapa pelaku UKM belum mempunyai pemahaman mengenai laporan keuangan, dengan cara mengadakan pelatihan atau seminar kepada pelaku UKM 


\section{DAFTAR PUSTAKA}

Anwar, S. (2016). Metodologi Penelitian Bisnis. Jakarta: Salemba Empat. In IOSR Journal of Economics and Finance.

Arbi Siti, R. H. M., Bismo, A., \& Sutiyo, L. (2019). Segmentation analysis of Instagram Users Based on Preferences towards Forms and Types of Online Marketing Content. Proceedings of 2019 International Conference on Information Management and Technology, ICIMTech 2019. https://doi.org/10.1109/ ICIMTech.2019.8843797

Arikunto, S. (2012). Prosedur Penelitian : Suatu Pendekatan Praktik (Edisi Revisi). In Rineka Cipta.

Arumsari, D. T. (2019). Pengaruh Literasi Keuangan dan Kompetensi SDM Terhadap Kinerja UKM di Jawa Timur. STIE Perbanas Surabaya.

Chepngetich, P. (2016). Effect of Financial Literacy and Performance SMEs. Evidence from Kenya. In American Based Research Journal.

Curtiss, J. 2012. Determinants of Financial Capital Use: Review of theories and implications for rural businesses (No. 545-2016-38712).

Dahmen, P., \& Rodríguez, E. (2014). Financial Literacy and the Success of Small Businesses: An Observation from a Small Business Development Center. Numeracy. https:// doi.org/10.5038/1936-4660.7.1.3

Eniola, A. A., \& Dada, D. A. (2018). The Performance of Women Entrepreneurs: Human and Financial Capital. In Trtiple A Research Journal of Social Science and Humanity (TARJSSH) I.

Fatoki, O. (2014). The Financial Literacy of Micro Entrepreneurs in South Africa. Journal of Social Sciences. https:// doi.org/10.1080/09718923.2014.11893311

Fatoki, O. O. (2011). The Impact of Human, Social and Financial Capital on the Performance of Small and Medium-Sized Enterprises (SMEs) in South Africa. Journal of Social Sciences. https://doi.org/10.1080/09718923.2011.11892970

Ghozali, I. (2011). Aplikasi Analisis Multivariate dengan Program IBM SPSS 19, Edisi 5, Badan Penerbit Universitas Diponegoro, Semarang. Terhadap Penghindaran Pajak Di Perusahaan Manufaktur, Skripsi, Fakultas Ekonomi Universitas Indonesia, Jakarta.

Harahap, Y. R. (2014). Kemampuan menyuun laporan keuangan yang dimiliki pelaku UKM dan pengaruhnya terhadap kinerja UKM. Journal of Accounting and Business Research.

Idawati, I. A. A., \& Pratama, I. G. S. (2020). Pengaruh Literasi Keuangan Terhadap Kinerja dan Keberlangsungan UMKM di Kota Denpasar. Warmadewa Management and Business Journal (WMBJ). https://doi.org/10.22225/wmbj.2.1.1644.1-9

Kurniawan, B. (2017). Sistem Informasi Akuntansi, Literasi Keuangan Dan Kinerja Usaha Ukm Distro: Studi Di Distro Yogyakarta Dan Solo (Doctoral dissertation, Institut Agama Islam Negeri Surakarta).

Maghfiroh, T., Setiani, O., Sumarni, S., Supriyana, \& Adiani, F. (2016). The Effect Of Stimulus Cutaneous Slow Stroke Back Massage To Beta Endorphin Levels And Blood Pressure Changes Among Pregnant Women With Preeclampsia In Demak, Indonesia. 4th Asian Academic Society International Conference (AASIC) 2016 Globalizing.

Md Saad, A. (2018). The Influence of Human and Financial Capital on the Performance of Woman Entrepreneurs in Micro and Small Entreprises in State of Perak, Malaysia. Global Journal of Management and Business.

Ningsih, S. E. (2018). Pengaruh Literasi Keuangan Terhadap Kinerja Usaha Mikro, Kecil Dan Menengah Di Kabupaten Jember. Monopoli Dan Persainganm Usaha Tidak Sehat Pada Perdagangan Produk Air Minum Dalam Kemasan.

Otoritas Jasa Keuangan, 2016, Peraturan Otoritas Jasa Keuangan Nomor 29/POJK.04/2016 tentang Laporan Tahunan Emiten atau Perusahaan Publik, Jakarta: Otoritas Jasa Keuangan Republik Indonesia. 
OJK. (2019). Laporan Kinerja 2019. Otoritas Jasa Keuangan.

Pramestiningrum, D. R., \& Iramani, I. (2020). Pengaruh literasi keuangan, financial capital, kebijakan pemerintah terhadap kinerja usaha pada usaha kecil dan menengah di Jawa Timur. Journal of Business and Banking. https:// doi.org/10.14414/jbb.v9i2.1750

Priyatno, D. (2012). Cara kilat belajar analisis data dengan SPSS 20. Yogyakarta: Andi Offset.

Putri, H. K., \& Satria, D. (2019). Analisis Pengaruh Literasi Dan Inklusi Keuangan Terhadap Kinerja Pelaku Usaha Kecil Dan Menengah (Ukm) (Studi Kasus Pelaku Usaha Kecil Dan Menengah Kota Malang). Jurnal Ilmiah.

Rakhmawati, D., Widodo, S., \& Mujiyono. (2017). Analisis Permasalahan Pusat Informasi Konseling Remaja dalam Mewujudkan Masyarakat Berwawasan Kependudukan. Jurnal Konseling GUSJIGANG.

Rapih, S. (2015). Analisis Pengaruh Kompetensi Sumber Daya Manusia (Sdm), Modal Sosial Dan Modal Finansial Terhadap Kinerja Umkm Bidang Garmen Di Kabupaten Klaten. Assets: Jurnal Akuntansi Dan Pendidikan. https://doi.org/10.25273/jap.v4i2.685

Sanistasya, P. A., Raharjo, K., \& Iqbal, M. (2019). Pengaruh Literasi Keuangan dan Inklusi Keuangan Terhadap Kinerja Usaha Kecil di Kalimantan Timur. Jurnal Economia.

Setiawan, D., Kurniawan, B., \& Payamta, P. (2018). Dampak penggunaan e-filling terhadap kepatuhan wajib pajak: peran perilaku wajib pajak sebagai variabel mediasi. Jurnal Akuntansi \& Auditing Indonesia. https://doi.org/10.20885/jaai.vol22.iss1.art2

Sombolayuk, W., Yusup, R. M., \& Sudirman, I. (2019). Studi Hubungan Antara Modal Manusia, Modal Sosial, Dan Modal Keuangan Dengan Strategi Inovasi Perusahaan UKM. SIMAK. https:// doi.org/10.35129/simak. v17i01.69 